\title{
Yuri Biondi*
}

\section{Empowering Market-Based Finance: A Note on Bank Bailouts in the Aftermath of the North Atlantic Financial Crisis of 2007}

\author{
DOI 10.1515/ael-2016-0004
}

\begin{abstract}
The North Atlantic Financial Crisis of 2007 did suddenly and massively disrupt the activities of financial markets and financial institutions that were organised under a market-based financial architecture at local and international levels. Both corporate and public policies were at the origin of this financial organisation that was established since the seventies and put at issue by this crisis. Finance and government were then as much complementary as rival actors throughout this market-driven transformation of local and international financial systems. Bank bailouts of 2007-2008 may be situated in this comprehensive and historical pattern, and embedded in the institutional structure that was designed and implemented to organise trans-national financial markets and financialisation.
\end{abstract}

Keywords: financial regulation, global financial crisis, corporate governance, accounting regulation

\section{Symposium on 'The Power of Inaction. Bank Bailouts in Comparison' by Cornelia Woll}

1 Cornelia, Woll (2016) 'A Symposium on Financial Power', Accounting, Economics and Law: A Convivium, DOI 10.1515/ael-2016-0001.

2 Kelsey M. Barnes and Arthur E. Wilmarth (2016) 'Explaining Variations in Bailout Policies: A Review of Cornelia Woll's The Power of Inaction', Accounting, Economics and Law: A Convivium, DOI 10.1515/ael-2015-0012.

3 Matthias Thiemann (2016) 'The Power of Inaction or Elite Failure? A Comment on Woll' "The Power of Inaction"', Accounting, Economics and Law: A Convivium, DOI 10.1515/ael-2015-0011.

4 Philippe Moutot (2016) 'Power of Inaction or Ability to Learn in Action within a Political Process? Comments on "The Power of Inaction" by Cornelia Woll', Accounting, Economics and Law: A Convivium, DOI 10.1515/ael-2015-0009.

5 Raphael Reinke (2016) 'The Power of Banks and Governments', Accounting, Economics and Law: A Convivium, DOI 10.1515/ael-2016-0003.

6 Jason O. Jensen (2016) 'Comment on The Power of Inaction by Cornelia Woll', Accounting, Economics and Law: A Convivium, DOI 10.1515/ael-2015-0010.

*Corresponding author: Yuri Biondi, ESCP Europe (Labex ReFi), avenue de la Republique, Paris 75011, France, E-mail: yuri.biondi@gmail.com 
7 Yuri Biondi (2016) 'Empowering Market-Based Finance: A Note on Bank Bailouts in the Aftermath of the North Atlantic Financial Crisis of 2007', Accounting, Economics and Law: A Convivium, DOI 10.1515/ael-2016-0004.

8 Cornelia Woll (2016) 'A Rejoinder by the Author', Accounting, Economics and Law: A Convivium, DOI 10.1515/ael-2016-0005.

Cornelia Woll's book provides a comprehensive and insightful empirical analysis of bank restructuring processes in six jurisdictions in the aftermath of the Global Financial Crisis. Her timely analysis shed light on this crisis that originated in Anglo-American contexts and spread through global financial institutions across national jurisdictions, forcing local authorities to intervene. In fact, it may be labelled North Atlantic Financial Crisis of 2007 due to its origin, as was the case for the Asian Financial Crisis of 1997. The "global" label appears to somewhat undermine issues of contagion and interdependency that were critical in the crisis mechanics. These issues are at the core of both bank resolution and socioeconomic impact. This impact spread across local financial systems through a market-based financial architecture that was designed and implemented to foster and enable global financial markets and financialisation of national and international economic affairs. From this perspective, the "global" label diverts attention from its very origin and related issues, raising the question of the "productive power" of finance - that is, its capacity to produce subjects and drive the public debate through systems of knowledge and discourse, according to Woll's definition of this epistemic, ideological and rhetoric power.

All the commentaries and the author's introduction and rejoinder included in this book review symposium do carefully consider Woll's analysis, its contribution, limits and implications for understanding and possibly improving bank restructuring processes. Some further elements may be considered which stand behind those processes, concerning: the state/market divide; the marketbased financial architecture and its crisis; and the monetary and institutional interventions that helped rescuing the financial system besides (and behind) bank restructuring. All these elements point to the legal and institutional setting stressed by Moutot's and Thiemann's commentaries. This setting frames and shapes the political inter-action between government and finance, while it can be and has been reframed and reshaped by this interaction.

From a theoretical viewpoint, several decades of quite misleading economic analysis has opposed state and market as antagonistic institutional regimes, and powers. In fact, they do complement and sustain each other as much as they are distinctive and distinct. We may argue that the very basis of finance stands upon a legal structure, since financial instruments including the legal tender have a legal dimension which is integral to their nature and working operation. While 
labor relations can exist without such legal instrumentality, shares, bonds and derivatives cannot.

From a political-economic viewpoint, government interventions in guaranteeing bank liabilities and taking over bank bad assets did factually (and materially) extend the perimeter of protected monetary instruments from deposits to other financial securities and activities, broadening the monetary basis and related financial coverage at least on temporary basis. This dynamics shows significant complementarities and interdependencies which must be understood and regulated, pointing to the the link between banking, government and the monetary institutions (IMF, 2015; Moe, 2015).

In this context, the market-based finance which collapsed during the North Atlantic Financial Crisis has been enabled not only by financial corporate policies and strategies, but also by a series of top-down reforms and political moves, mainly after the disband of the Bretton Woods Accords, often driven by international institutions and agreements, and originated in Anglo-American contexts. Concerning the US context, we may mention the reform of US pension funds since the seventies (Biondi \& Boisseau, 2015), the progressive decline and repeal of the Glass-Steagall Act since the eighties (Wray, 2013), the progressive endorsement by allowance or requirement of mark-to-market and fair value accounting measurements especially for financial assets and liabilities since the nineties (Allen \& Ramanna, 2013), and the Commodity Futures Modernization Act of 2000 (Stout, 2011, commented by Biondi, 2011 and Pradier, 2011), along with the permissive supervisory policy that left US financial institutions overdeveloping their mortgage-backed securities market-making.

Once this market-based finance disrupted, since the summer of 2007, governments stepped behind it. These interventions were not limited to rescue insolvent financial institutions, but included a broader set of actions besides bank restructuring.

For instance, the AIG rescue by the US Federal Reserve - exercising its emergency powers under section 13(3) of the Federal Reserve Act - was critical to uphold the financial system in US and abroad. Insurance contracts were a key element of the financial processes behind marketable financial contracts and related inter-bank reciprocal obligations. If AIG - the main insurer of them disrupted, the contagion would have spread even more largely and intensively.

Moreover, a stampede of financial institutions were enabled to merge with and reincorporate as insured depository institutions in the United States, making them qualified for Capital Purchase Plan (CPP) and Federal Deposit Insurance Corporation (FDIC) money, certainly easing their institutional and prudential constraints. 
Last but not least, mark-to-market accounting was suspended in both US and Europe (Bignon, Biondi, \& Ragot, 2009), enabling financial institutions to avoid recognising losses and impairments - including goodwill impairment - on their portfolios at current market prices that had collapsed. However, this did not pave the way to a comprehensive reconsideration of the new accounting model of reference for financial institutions, a model that has been designed upon a mark-to-market basis, and proved to be pro-cyclical and dysfunctional for financial stability and sustainability (Biondi \& Giannoccolo, 2015).

Concerning monetary interventions, the central banks in both US and UK complemented inter-bank refinancing facilities whose activity was disrupted, upholding both governmental financial capacity and inter-bank credit. Generally speaking, this was done by expanding the monetary basis to include financial securities issued or held by both financial institutions and governments backed by those central banks (Biondi, 2014; Pistor, 2012).

While all this manoeuvring was effective in copying with the global spread of the North Atlantic Financial Crisis, it did also enable finance to not fully acknowledge its overarching corporate social responsibility concerning sustainable financing for economy and society. Both the "game of chicken" and the resistance to cooperate by some leading financial institutions - stressed by Woll's analysis and discussed by its commentators - were surely eased and even enabled by the institutional and monetary interventions mentioned above.

In the aftermath of the North Atlantic Financial Crisis, influential public reports and statements stated several fundamental issues and concerns (for instance, the Turner Review: FSA, 2009; Volcker, 2009), foreshadowing the limits and hazards of a market-based financial architecture. However, and unfortunately, the political window that was opened in the aftermath of the crisis to comprehensively address these issues and concerns appears having been progressively closed.

As Mark Carney (2014, p.3), Governor of the Bank of England, states: "Capitalism loses its sense of moderation when the belief in the power of the market enters the realm of faith. In the decades prior to the crisis, such radicalism came to dominate economic ideas and became a pattern of social behaviour. As Michael Sandel argued, we moved from a market economy to a market society. Market fundamentalism - in the form of light-touch regulation, the belief that bubbles cannot be identified and that markets always clear - contributed directly to the financial crisis and the associated erosion of social capital", which "refers to the links, shared values and beliefs in a society which encourage individuals not only to take responsibility for themselves and their families but also to trust each other and work collaboratively to support each other."

"What will History say?" Remembering Bertrand Shaw (1901, third act 'The Devil's Disciple')'s General Burgoyne's reply, "History, Sir, will tell lies, as 
usual". Temptation is now strong to forget the lessons from the eighties, the nighties and the North Atlantic Financial Crisis of 2007, coming back to market-based finance as usual along with validation of those emergency measures. This would leave unaddressed the underlying issues and concerns, including national, regional and international regimes for debt restructuration and bank bailout and resolution. The contribution by Woll's book and its commentators does effectively resist this temptation, seeking for facts and analysis to reach a better understanding of a major historical event.

Acknowledgement: Tenured Senior Research Fellow of the Cnrs (France) and Research Director at the Financial Regulation Research Lab (Labex ReFi), Paris, France. I wish thanking Thornvald Moe, Philippe Moutot, Cornelia Woll and all the other speakers and participants to the "Author meets Critics" session held at the SASE 2015 Annual Meeting (LSE, London, 2-4 July). I am grateful to Linn Anker for inspiring conversations. Usual disclaimer applies.

\section{References}

Allen, A., \& Ramanna, K. (2013). Towards an understanding of the role of standard setters in standard setting. Journal of Accounting and Economics, 55(1), 66-90. doi:http://dx.doi. org/10.1016/j.jacceco.2012.05.003

Bignon, V., Biondi, Y., \& Ragot, X. (2009). An economic analysis of fair value: Accounting as a vector of crisis. Cournot Centre for Economic Studies, Prisme, No.15, 2009. Retrieved from http://ssrn.com/abstract $=1474228$

Biondi, Y. (2011). Disagreement-based trading and speculation: Implications for financial regulation and economic theory. Accounting, Economics, and Law: A Convivium, 1(1). doi:http://dx.doi.org/10.2202/2152-2820.1017

Biondi, Y. (2014). The strange case of doctor Jekyll (Alias the UK HM Treasury) and Mr Hyde (alias its public debt management) in the aftermath of the global financial crisis. Paper prepared for the 12th World Congress of the International Association for Accounting Education and Research (IAAER), November 13-15, 2014 - Firenze, Italy. DOI: http://dx.doi. org/10.2139/ssrn.2411048

Biondi, Y., \& Boisseau, M. (2015). Pension management between financial market development and intergenerational solidarity: A socio-economic analysis and a comprehensive model. EGPA 2015 Annual Conference, Toulouse, 26-28 August 2015. doi:http://dx.doi.org/10. $2139 /$ ssrn. 2661718

Biondi, Y., \& Giannoccolo, P. (2015). Share price formation, market exuberance and financial stability under alternative accounting regimes. Journal of Economic Interaction and Coordination, 10(2), 333-362. doi:http://dx.doi.org/10.1007/s11403-014-0131-7

Carney, M. (2014). Inclusive capitalism: Creating a sense of the systemic. Speech given by the Governor of the Bank of England at the Conference on Inclusive Capitalism, London: 27 May 2014. Retrieved from http://www.bankofengland.co.uk/publications/Pages/ speeches/2014/731.aspx 
FSA - Financial Services Authority. (2009). The turner review. A regulatory response to the global banking crisis, March, London. Retrieved from http://www.fsa.gov.uk/pubs/other/ turner_review.pdf

International Monetary Fund. (2015). From banking to sovereign stress: Implications for public debt. December 22, Washington, DC.

Moe, T. (2015). Shadow banking: Policy challenges for central banks. The Journal of Financial Perspectives, 3(2), 31-42. EY Global Financial Services Institute.

Pistor, K. (2012). Real vs. Imagined Financial Markets. The Regulatory Challenge, Paper prepared for the 3rd Annual INET Conference, Berlin, 10-12 April 2012. Retrieved from http:// works.bepress.com/katharina_pistor/12.

Pradier, P. -Ch. (2011). Administering systemic risk vs. administering justice: What can we do now that we have agreed to pay differences? Accounting, Economics, and Law: $A$ Convivium, 1(1). doi:http://dx.doi.org/10.2202/2152-2820.1015.

Randall, W. L. (2013). What do banks do? What should banks do? A minskian perspective. Accounting, Economics, and Law: A Convivium, 3(3). doi:http://dx.doi.org/10.1515/ael2013-0033.

Shaw, George Bernard (1901). The Devil's Disciple (First ed.). London: G. Richards.

Stout, L. (2011). Risk, speculation, and OTC derivatives: An inaugural essay for convivium. Accounting, Economics, and Law: A Convivium, 1(1). doi:http://dx.doi.org/10.2202/21522820.1004.

Volcker, P. (2009). The only thing useful banks have invented in 20 years is the ATM. New York Post, 13 December 2009. Retrieved from http://nyp.st/1a1ZS9p

Wray, R. L. (2011), What do banks do? What should banks do? A minskian perspective. Accounting, Economics and Law: A Convivium, 3(3), 277-311. doi:http://dx.doi.org/ 10.1515/ael-2013-0033, April 2013. 